\title{
Right to Education under European Convention for the Protection of Human Rights and Fundamental Freedoms 1950
}

\author{
Sheeba Pillai*
}

\begin{abstract}
Right to education is one of the most important human rights and has been widely so acknowledged in several international and regional documents related to human rights. These documents have defined the right in an elaborate manner placing a lot of emphasis on compulsory elementary education and thereby making it obligatory on the states to provide the same and also guarantee equality of accessibility of education at higher levels. The European Convention on Human Rights 1950 has guaranteed the right to education in Article 2 of Protocol 1.Unlike the International Covenant on the Economic, Social and Cultural Rights 1966 or the other regional documents, the European Convention on Human Rights 1950 has not defined the right to education in an elaborate manner, in the document. Thus, the burden of making the right to education more resourceful fell largely upon the shoulders of the enforcement mechanism, they being European Court and European Commission of Human Rights, both constituted by the Convention. This article makes an analysis of the right to education as interpreted by these two authorities.
\end{abstract}

Keywords: Compulsory Education, ECHR, Human Rights, Right to Education

* Assistant Professor, School of Indian Legal Thought, Mahatma Gandhi University, Kottayam, Kerela. 


\section{Introduction}

Right to education is one of the most precious of human rights, which can transform an illiterate and ignorant society to a literate and enlightened one. From time immemorial, the importance of education has been discussed and reiterated through various debates, conferences, documents, both at national and international level.

Though the United Nations an international body of universal status was responsible for addressing the issue of human rights in general, it was the adoption of the Universal Declaration of Human Rights, 1948, followed by the other international covenants that made fundamental inroads into the domain of protection of human rights thereby making crucial references to the right to education. The Universal Declaration of Human Rights, 1948 which was one of the first documents to give due recognition to the right to education lays down that everyone has the right to education. Education shall be compulsory. ${ }^{1}$ This was reiterated in several other documents. ${ }^{2}$

Facets of right to education can also be found in regional human right treaties and declarations. ${ }^{3}$ The European Convention for the

${ }^{1}$ Universal Declaration of Human Rights, G.A. res. 217A (III), U.N. Doc A/810 at 71 (1948), art. 26.

2 International Covenant on Civil and Political Rights, Dec. 16, 1966, S. Treaty Doc. No. 95-20, 6 I.L.M. 368 (1967), 999 U.N.T.S. 171, at art.13 (recognizing the right to education almost on similar lines as the Universal Declaration of Human Rights).

${ }^{3}$ European Convention on Human Rights, (Nov. 4, 1950), Europ.T.S. No. 5; 213 U.N.T.S. 221, art. 2 Protocol No.1; American Declaration of Rights and Duties of Man,1948, Res. XXX, Final Act of the Ninth International Conference of American States (Pan American Union), Bogota, Colombia, (Mar. 30-May 2, 1948), art. 12: American Convention on Human Rights (Nov. 21, 1969), O.A.S. T.S. No. 36; 1144 U.N.T.S. 143; S. Treaty Doc. No. 95-21, 9 I.L.M. 99(1969), art. 26; Additional Protocol to American Convention on Human Rights in the area of Economic, Social and Cultural Rights (Protocol of San Salvador), O.A.S. Treaty Series No. 69 (1988), entered into force (November 16, 1999), reprinted in Basic Documents Pertaining to Human Rights in the Inter-American System, OEA/Ser.L.V/II.82 doc.6 rev.1 at 67 (1992), art. 13 (stating that primary 102 
Protection of Human Rights and Fundamental Freedoms, 19504 (hereinafter referred to as ECHR) which is described as one of the greatest achievements of the Council of Europe is often spoken of as a major contributor of human rights law, not only at the regional but also at the global level. A unique aspect about the ECHR is that it is the only international human right instrument to adopt a negative formulation of right to education - 'that no person shall be denied the right to education.' This negative formulation was adopted because at the time, all members of Council of Europe had a general education system and it was unnecessary to require member states to establish such a system. Moreover, the state parties were reluctant to adopt a positive obligation as they knew very well that it would create an additional duty and bind them to take effective actions to enable each and every person to have access to instruction. ${ }^{5}$

Unlike other regional documents, the ECHR has played a dominant role in influencing the states in that region. In a substantial number of state parties, the ECHR enjoys the status of domestic law. ${ }^{6}$ Thus,

education should be compulsory and accessible to all without cost); African(Banjul) Charter on Human and Peoples Right, (June 27, 1981), 1520 U.N.T.S. 217, 245; 21 I.L.M. 58,59 (1982), art.17; African Charter on Rights and Welfare of the Child, (11 July 1990), CAB/LEG/24.9/49 (1990), art. 11 (guaranteeing right to education .Cl(3) of the Art grants free and compulsory education and also ensures equal access); Convention on Human Rights and Fundamental Freedoms of the Commonwealth of Independent States, Minsk, (26 May 1995), art. 27 (stating that elementary and fundamental education of a general shall be compulsory and free of charge); Arab Charter on Human Rights, (15 September 1994), art. 34 (stating that eradicating illiteracy is a commitment and obligation; Education is a right for every citizen. Elementary education is free and compulsory. Secondary and University education shall be accessible to all).

${ }^{4}$ European Convention on Human Rights, supra note 3.

5 Buren Van Geraldine, International Law ON The Rights OF The CHILD 233 (Springer Publishers 1995).

6 A.DRZEMCZAOSKI, EUROPEAN CONVENTION ON HUMAN RIGHTS IN DOMESTIC LAW-A COMPARATIVE STUDY (Oxford University Press 1998); see also Jörg Polakiewicz \& Valérie Jacob-Foltzer, The European Human Rights Convention in Domestic Law: The Impact of Strasbourg Case-Law in States 
in such countries, this Convention may be invoked as law in the national courts and they create rights which are directly enforceable by the individuals. However, in countries where this Convention does not enjoy the status of domestic law, legislation may be made to implement and enforce the rights envisaged in the Convention. Those countries who have not accorded the status of domestic law to the ECHR may refrain from totally ignoring the same, and the national courts often look to the ECHR while interpreting and applying the domestic law. ${ }^{7}$

Human rights jurisprudence of this region has evolved largely through the creativity shown by the enforcement mechanisms under the ECHR, namely the European Court and the European Commission on Human Rights. European Court and the European Commission on Human Rights have played a dynamic role in interpreting and moulding the various rights couched in the Convention. This article makes a critical evaluation of the right to education as interpreted by European Court and the European Commission on Human Rights.

\section{Right to Education}

Right to education has been guaranteed under Article 2 of the Protocol 1 of the ECHR which states that no person shall be denied the right to education. In the exercise of any functions which it assumes in relation to education and teaching, the state shall respect the right of parents to ensure such education and teaching is in conformity with their religious and philosophical convictions. Thus, the ECHR has formulated the right to education in a negative tone. It does not actually confirm that everyone has a right to education, but lays down that no one shall be denied the same.

Where Direct Effect is given to the Convention, 12 Human RIGHTS LAW JOURNAL 125 (1991).

${ }^{7}$ Higgins, The European Convention on Human Rights, in HUMAN RIGHTS IN INTERNATIONAL LAW: LEGAL AND POLICY ISSUES 495 503-505 (T. Melon et al.eds., $1^{\text {st }}$ ed. 1984); THOMAS BUERGENTHAL, SELF EXECUTING AND NON SELF EXECUTING TREATIES IN NATIONAL AND INTERNATIONAL LAW 235 Recueil des Cours, 303-05 (1992). 
Does this imply a weaker state responsibility in ensuring that this right is available to one and all? It could also mean that all persons have this right and the state shall ensure that this right is not taken away. In other words, the state has a definite obligation to protect the same either way.

However, when we examine the components of right to education as is formulated by many international and regional documents, 8 it is quite clear that right to education at the primary level emphasized on free and compulsory education, equality in opportunity and quality. With respect to higher education, wherever the same is mentioned, it focuses on equal accessibility only. ${ }^{9}$ The ECHR gave a restrictive description to the right, thus leaving it to the European Court and the European Commission on Human Rights to infuse life into the same.

\section{An Analysis of Right to Education as Interpreted by the European Commission on Human Rights and the European Court}

The wording in Article 2 of Protocol 1 of ECHR does not expressly mention any specific stage of education. But if we read both the lines together, it indicates that since the rights of parents to ensure such education and teaching is in conformity with their own religious and philosophical conviction has been referred to, it would indicate, that at a primary level as parental right is referred to, it is obviously with respect to minor children. But in the Case Relating to certain aspects of The Laws on the Use of Languages in Education in Belgium v. Belgium, ${ }^{10}$ summarizing the argument of the European Human Rights Commission the European court said that the Commission emphasizes that the first sentence of Article 2 of First Protocol of ECHR, despite its negative wording embodies the right to education of everyone. It is a right whose scope is not

8 International Covenant on Civil and Political Rights, supra note 2. See also European Convention on Human Rights, supra note 3.

${ }^{9} \mathrm{Id}$.

10 (No. 2) (1968), 1 E.H.R.R. 252. 
defined or specified in the ECHR and whose content varies from one time or place to another, according to economic and social circumstances. Belgium being a highly developed country the right to education for the purpose of considering the present case includes entry to nursery, primary, secondary and higher education. ${ }^{11}$ Citing this case, the Court of Appeals in United Kingdom in another case ${ }^{12}$ said that the European Court was plainly not considering adult education. Finally, the court came to the conclusion that Article 2 of the Protocol 1 of ECHR does apply to tertiary education. ${ }^{13}$

In several instances, the European Human Rights Commission had an occasion to examine whether the right to education includes primary, secondary and even adult education. In $Y v$. U.K. ${ }^{14}$ the European Human Rights Commission concluded that right to education envisaged in the Article 2 of Protocol 1 of ECHR was concerned primarily with elementary education and not necessarily advanced studies such as technology. Also, in Yanasik v. Turkey, ${ }^{15}$ the European Human Rights Commission said that right to education contemplated in the provision ruled mainly on concerns of elementary education and not necessarily specialist advanced studies. Again, in Leyla Sahin v. Turkey, 16 the European Court held that while the first sentence of Article 2 of Protocol 1 of ECHR essentially establishes access to primary and secondary education, there is no watertight division separating higher education from other forms of education.

The Council of Europe has stressed the key role and importance of higher education in promotion of human rights and fundamental freedom and strengthening of democracy. Consequently it would

${ }^{11} \mathrm{Id}$.

12 R (Douglas) v. North Tyneside Metropolitan Borough Council and Another, (2003) E.W.C.A. Civ. 1847.

${ }^{13}$ Id. 144 , at 720.

14 (1975) 2 D.R. 50.

15 (1993) 74 D.R. 14.

16 General Comment No. 44774/98 (2004). 
be hard to imagine that institution of higher education existing at a given point do not come within the scope of the first sentence of the Article 2 of ECHR. Till this point we may be almost convinced that there is a possibility of higher education also being considered in the said Article of Protocol 1 of ECHR. But this is dampened by the following opinion of the European Court where it held that although the Article 2 of Protocol 1 of ECHR does not impose a duty on the concerned states to set up institution of higher education, any state doing so, will be under an obligation to afford an effective right of access to them. But there is no compulsion on the states to set up institutions of higher education, how can we envisage a right to higher education under Article 2 of Protocol 1 of ECHR?

Thus, in most of the decisions we find that the European Human Rights Commission and the European Court rejected the contention that the level of education referred to was higher education but there does not seem to be a consensus on the subject. As parental right has been given predominance it would in all probability refer to minor children and so the level of education referred to will also be primary education and at most secondary but not beyond that.

\section{Free and Compulsory Education}

The judgment in Belgian Linguistic Case ${ }^{17}$ was one of the first to elaborate the content of Article 2 of Protocol 1of ECHR. Six groups of applicants claimed that various aspects of the Belgian legislation governing the use of languages in schools were inconsistent with the ECHR. Different aspects of the legislation were challenged by the French speaking parents residing in the Dutch speaking area of Belgium. ${ }^{18}$

The negative formulation of the right to education restricted the European Court from giving an expansive meaning to the right. The European Court held that the right to education does not imply a duty on the state party to provide free or subsidized education of

17 (No.2) (1968) 1 E.H.R.R. 252.

${ }_{18} \mathrm{Id}$. 
a specific type or a specific level. But the court confirmed that there was a right to access for individuals to the existing educational institutions and for individuals to receive official recognition of the studies they have undertaken. ${ }^{19}$ Further, they also said there is no obligation on the part of the state to establish or fund any particular type of educational institution. The European court expressly observed that the first sentence of Article 2 of Protocol 1 of ECHR left the states with the discretion to decide whether or not to subsidize private schools. ${ }^{20}$ Thus, the court did not touch upon the concept of compulsory education. On the other hand, though it made a reference to free education, it was only to submit that the state does not have the obligation to set up new institutions or provide subsidized education. This standpoint is different from the view taken in several other human rights instruments which have emphasized on free and compulsory education as a state obligation at least up to the primary level of schooling. In $X v$. Belgium, the European Human Rights Commission said that the state parties are not obliged to provide adult education. ${ }^{21}$ The Commission also stated that there is no duty to guarantee the availability of schools in accordance with certain religious convictions of parents. ${ }^{22}$

But an altogether different opinion emerged in the case of Family $\mathrm{H}$ v. The U.K. ${ }^{23}$ While considering the question as to whether the choice of education includes the right to be educated at home, the European Human Rights Commission stated that it is clear that Article 2 of Protocol 1 of ECHR implies a right of the state to establish compulsory schooling be it in the state schools or private tuition of a satisfactory standard. The European Human Rights Commission concluded that to require the applicant's parents to cooperate in the assessment of their children's educational standards done by an educational authority in order to ensure a certain level

19 Church of X v. U.K., Application No.3798/68 12 Yearbook 306 (stating that there should be official recognition of any completed educational studies).

${ }^{20} \mathrm{Id}$. (acknowledging the State's authority to regulate the right to education).

21 D.R. 3 (1976), 162 (164).

${ }^{22} \mathrm{X}$ and Y v. U.K., D.R/ 11(1978) at 147.

23 D.R. 37 (1984) at 105. 
of literacy and numeracy, whilst nevertheless allowing them to educate their children at home cannot be said to constitute a lack of respect for the applicant's rights under Article 2 of Protocol 1 ECHR. ${ }^{24}$ Thus, the concept of compulsory schooling has been expressly stated by the European Human Rights Commission and further they have also made reference to the quality of education that must be delivered to the student.

\section{Role of Private Bodies in Providing Compulsory Education}

In any state, compulsory education can be effectively carried out if the state is assisted in its functions by private bodies. International law allows non state schools to exist, but does not place a duty on the states to create favorable conditions for their existence. There is nothing in international law which places the state under a duty to create conditions in which private schools can flourish. ${ }^{25}$

A dynamic view was taken in this matter by the European Human Rights Commission in Kjeldsen, Busk Madsen and Pedersen $v$. Denmark, ${ }^{26}$ where it stated that the right to establishment of and access to private schools or other means of education outside the public school system falls under the provision of Article 2 of the ECHR. In its judgment, the court restricted itself to holding that the travaux preparatories indisputably demonstrate the importance attached by many members of the Consultative Assembly and a number of governments freedom to teach, that is to say, freedom to establish private schools. In the European Human Rights Commission's view, the first sentence of Article 2 of the Protocol 1 of ECHR, guarantees the right to establish and run a private school, but does not contain a positive obligation for the state to fund it. ${ }^{27}$

24 Id. at 106.

${ }^{25}$ GERALDINE, supra note 5 at 243.

26 (1976) 1 E.H.R.R. 737.

27 Ingrid Jordebo Foundation of Christian Schools and Ingrid Jordebo v. Sweden, D.R. 51 (1987) at 125,128; see also Verein Gemeinsam Lernen v. Austria, D.R. 82-A (1995) at 41, 45. 
Commenting on the disciplinary action taken by a private school, the court in Costello Roberts v. U.K.28 held that a school's disciplinary system falls within the right to education (reiterated the decision in Campbell $v$. Cosans ${ }^{29}$ ) and that there would be no distinction between pupils in state and private schools. Significantly, the court held that treatment at private schools, which was incompatible with the ECHR, would engage a state party's responsibility under it. But state responsibility cannot be absolved by private bodies or individuals. Thus, it has been clearly brought out that though private bodies can participate with the government in providing right to education, it is only a secondary duty and the primary duty vests with the government which has the inherent obligation to provide free and compulsory education in an equitable manner.

\section{Parental Rights under ECHR}

The ECHR has given a lot of importance to the right of parents and its Protocol 1 acknowledges the obligation of the state to respect the right of parents to ensure such education and teaching is in conformity with their own religious and philosophical convictions. This duty of the states to respect the right of parents is also enshrined in the Additional Protocol to the American Convention on Human Rights in the area of Economic, Social and Cultural Rights, $1988 .{ }^{30}$ What is meant by philosophical conviction is a little confusing. In fact at one stage in the preparatory work on the Protocol of ECHR, the text referred solely to the protection of

${ }^{28}$ Application No.131341/87.

29 (1982) 4 E.H.R.R. 293.

${ }^{30}$ American Convention on Human Rights (Nov. 21, 1969), O.A.S. T.S. No. 36; 1144 U.N.T.S. 143; S. Treaty Doc. No. 95-21, 9 I.L.M. 99(1969), art. 13(4) (stating that in conformity with domestic legislation of the state party, parents should have the right to select the type of education to be given to the children provided that it conforms to the principle set forth above). 
religious opinion, but the term 'philosophical' was added in order to cover agnostic opinions. ${ }^{31}$

In the Belgian Linguistic Case 32 , the Applicants argued that 'philosophical convictions' should be interpreted to include the cultural and linguistic preferences of parents. The European Human Rights Commission and the European Court in this respect was unanimous in considering that the second sentence of Article 2 of the ECHR was not intended to guarantee respect for preferences or opinions in cultural or linguistic matters, whether such opinions were considered as a part of the 'personalist philosophy 'of the applicants.

This aspect came up for discussion in several other cases. The European Court in the case of Kjeldsen, Busk Madsen and Pedersen ${ }^{33}$ stated that the state in discharging the function assumed by it in regard to education and teaching, must take care that information or knowledge included in the curriculum is conveyed in an objective, critical and pluralistic manner. The state is forbidden to pursue an aim of indoctrination which might be considered as not respecting parent's religious and philosophical convictions. ${ }^{34}$ The Applicants objected to the compulsory sex education in the state schools and after the authorities refused to exempt their children from such classes, they complained to the European Human Rights Commission alleging that their Christian beliefs had been violated by breach of Article 2 of the ECHR. According to the European Human Rights Commission, respect implies the need to balance the right of the state party's obligation to respect the right of parents. The European Human Rights Commission concluded that the state party had shown respect for the conditions in the way the subject was taught and inter alia the Danish system of sex education did not violate the relevant articles. In this case the court has produced

31 Francis G. Jacobs And Robin C.A. White, European CONVENTION ON HUMAN RIGHTS 264 (2nd ed. 1996).

32 Belgian Linguistic Case, (No.2) (1968), 1 E.H.R.R. 252.

33 (1976) 1 E.H.R.R. 737.

${ }^{34} \mathrm{Id}$. at 93. 
two more clarifications. First, the court rejected the submission of the Danish government that the provisions referred to specific religious instructions. According, to the court in all educational activities with which the government is concerned, the right of parents enshrined in Article 2 of ECHR have to be respected. 35 Second, the court clearly stated that the subjective views of the parents are not decisive for the question whether the content of the instruction is in conformity with their religious and philosophical convictions, this question should be examined by reference to objective criteria. The court held that the second sentence of Article 2 of the ECHR seeks to promote pluralism in education, which is essential for the preservation of democratic society as envisaged by the ECHR.

In Campbell v. Cosans, ${ }^{36}$ while discussing the parent's objection to corporal punishment in state schools where the child was pursuing his studies, ${ }^{37}$ the court clarified the concept of philosophical convictions. The court stated that the word conviction taken on its own is not synonymous with the words opinion and ideas as are utilized in Article 10 of the ECHR which guarantees freedom of expression. It is more akin to the term beliefs appearing in Article 9 of the ECHR which guarantees freedom of thought, conscience and religion and denote views that attain a certain level of cogency, seriousness, cohesion and importance. Further, the court said that the philosophical convictions in the present context are worthy of respect in a democratic society and are not incompatible with human dignity. In addition, they must not conflict with the fundamental right of a child to education. ${ }^{38}$ Thus, the court agreed that the parental objection to corporal punishment met this standard since it conceived the integrity of the person, the propriety or otherwise of the infliction of the corporal punishment and the exclusion of distress which such punishment entails.

${ }^{35} \mathrm{Id}$. at 925.

36 (1982) 4 E.H.R.R. 293.

${ }^{37} \mathrm{Id}$. (the child was subsequently suspended for one year for refusing to accept corporal punishment for taking a prohibited short cut through the cemetery).

38 (1982) 4 E.H.R.R. 293. 
The court has been confronted with wide range of situation concerning his aspect of Article 2 of Protocol 1 of ECHR. Similarly in Kjeldsen, Busk Madsen and Pederson Case, ${ }^{39}$ the allegation was that the compulsory ethics classes offended some of the parent's religious sentiments. ${ }^{40}$ In other cases, there was the question of religious teaching based on Sunni interpretation of Islam in conflict with the religious beliefs of Alexi faith, ${ }^{41}$ and religious teaching on Christianity conflicting with philosophical conviction of non Christian parents. ${ }^{42}$ The test applied in all these cases was that the state in fulfilling the function assumed by it in regard to education and teaching must ensure that information and knowledge included in the curriculum is conveyed in an objective and pluralistic manner. If this is not the case, the state authorities are under an obligation to grant children full exemption from the lessons in accordance with the wishes of the parents. Thus, we can see that though the parents have a right to have their children educated according to their convictions and beliefs, it must be properly balanced with the other rights guaranteed in the ECHR. Further, there does not seem to be any direct duty on the part of the state to create schools which are congenial to such parental beliefs or philosophy. At best, they can choose from what is already offered. One can also see that the right of parents is a qualified right and one cannot really give an expansive meaning to the same. The right of parents is restricted to the area of having their children educated according to their philosophical convictions and beliefs only.

\section{Quality and Accessibility of Education}

Quality of education has been accorded great importance as is evident from the decision in Family $H$ v. U.K. ${ }^{43}$ where the court

39 (1976) 1 E.H.R.R. 737.

${ }^{40}$ Appelrrang v. Germany, Application No. 45216/07 (2009).

${ }^{41}$ Hasan and Eylem Zengin v. Turkey, Application No. 1448/08 (2007).

42 Folgero and Others v. Norway, Application No. 15472/02, E.C.H.R. (2007).

4337 D.R. 105 (1984). 
permitting children to be educated at home, cautioned that such tuition must be in accordance with national educational standards. Irrespective of where the child is educated, the child must achieve the basic literacy and numeracy level. Again, while dealing with several applications concerning the placements of children with learning difficulties in special schools, the European Human Rights Commission has emphasized on the requirement of the balance to be stuck between the child's rights to have effective education and the beliefs expressed by the parents. ${ }^{44}$ This has been reiterated in several judgments. 45 Thus, one finds that the European Human Rights Commission and the European Court were determined to uphold the quality of education and did not allow the same to be compromised in any context.

In the Belgian Linguistic case ${ }^{46}$ the European Court stated that although the right to education would be meaningless unless it implied the right to be educated in one of the national languages, in the absence of any express term, Article 14 of ECHR, ${ }^{47}$ when read together with Art. 2 of Protocol 1, did not guarantee to everyone the right to obtain an education in the language of his or her choice. The court further explained that though the state was not obliged to establish and fund any particular type of educational institution, there was a right of access for individuals to existing educational institution and also for individuals to receive official recognition of the studies they have undertaken.

In Cyprus v. Turkey ${ }^{48}$ the court emphasized that any form of discrimination was a violation of the child's right to education. The court held that two violations had taken place. Violation of Article 2 of Protocol 1of ECHR in respect of Greek Cypriots living in northern Cyprus in so far as no appropriate secondary school

${ }^{44} \mathrm{X}$ and Y v. U.K., D.R. 11(1978) 147.

45 Application 13387/88, Graeme v. U.K., (1990) 64 D.R. 158.

46 (No. 2) (1968) 1 E.H.R.R. 252.

${ }^{47}$ European Convention on Human Rights, (Nov. 4, 1950), Europ.T.S. No. 5; 213 U.N.T.S. 221, art. 14 Protocol No.1.

48 Application No. 25781/94 (2001). 
facilities were available to them and violation of Article 14 of the ECHR $^{49}$ in that the Greek Cypriots living in Karpas area of northern Cyprus had been subjected to discrimination. The court called upon the Turkish authorities in Northern Cyprus to refrain from censoring Greek language textbooks. The court found that the closure of Greek medium secondary schools amounted to the denial of the right to education.

Conclusion

The ECHR does not provide an expansive description of the right to education, The European Human Rights Commission and the European Court were responsible in extending and infusing the essence of a right to right to education. They dealt with all the important ingredients of the right like compulsory education, equality of accessibility and quality. However, free and subsidized education was not stressed upon. The right to education would have been more meaningful if this aspect had also been read into right to education.

${ }^{49}$ European Convention on Human Rights, supra note 47. 